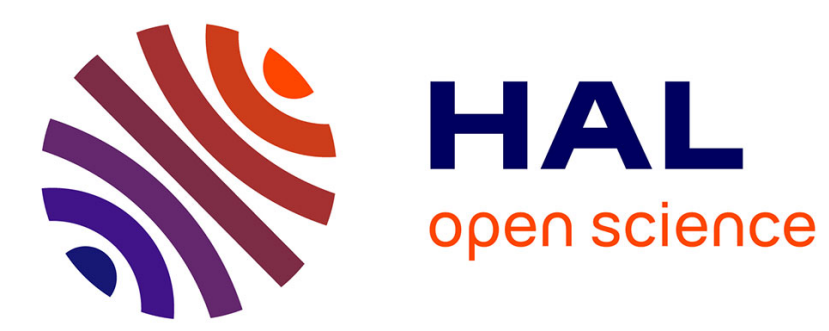

\title{
Structures and properties of Y-ZrO2 thin films deposited by reactive r.f. sputtering
}

\author{
Y.-H. Wang, X.-P. Li
}

\section{To cite this version:}

Y.-H. Wang, X.-P. Li. Structures and properties of Y-ZrO2 thin films deposited by reactive r.f. sputtering. Journal de Physique IV Proceedings, 1993, 03 (C3), pp.C3-611-C3-615. 10.1051/jp4:1993386 . jpa-00251443

\section{HAL Id: jpa-00251443 https://hal.science/jpa-00251443}

Submitted on 1 Jan 1993

HAL is a multi-disciplinary open access archive for the deposit and dissemination of scientific research documents, whether they are published or not. The documents may come from teaching and research institutions in France or abroad, or from public or private research centers.
L'archive ouverte pluridisciplinaire HAL, est destinée au dépôt et à la diffusion de documents scientifiques de niveau recherche, publiés ou non, émanant des établissements d'enseignement et de recherche français ou étrangers, des laboratoires publics ou privés. 


\title{
Structures and properties of $\mathrm{Y}-\mathrm{ZrO}_{2}$ thin films deposited by reactive r.f. sputtering
}

\author{
Y.-H. WANG and X.-P. LI \\ Dept. Materials Science and Engineering, Tsinghua University, Beijing 100084, China
}

\begin{abstract}
The $\mathrm{Y}-\mathrm{ZrO}_{2}$ thin films were deposited by $r . f$. magnetron sputtering method. The microstructure, phase composition and mechanical properties of the thin films were investigated. The studies show that the films had tiny grains, tetragonal phase, and the best properties when they were deposited at the condition of the low substrate temperature and zero oxygen partial pressure.
\end{abstract}

\section{Introduction}

Zirconia thin films have advanced mechanical, thermal, optical and electrical propeties that made them interesting for theoretical. studies and practical application (1-7). Bulk $\mathrm{ZrO}_{2}$ has three kinds of phases: low temperature monoclinic (M), high temperature tetragonal ( $T$ ) and cubic (C). Alloying certain stabilizers, such as $\mathrm{Y}_{2} \mathrm{O}_{3}, \mathrm{MgO}, \mathrm{CaO}$, and $\mathrm{CeO}$, the $\mathrm{T}$ or $\mathrm{C}$ phase can exist at room temperature. Recently, the martensitic transformation $(\mathrm{T} \rightarrow \mathrm{M})$ in the bulk materials had been found to be able to improve the fracture toughness and wear resistance ( 8$)$. Furthermore, a strengthing overcoat of $\mathrm{ZrO}_{2}$ thin films had been made $(4,5)$. However, they had not got the $T$ phase in the films.

A Y-TZP target had been used in our study, and $\mathrm{Y}_{-} \mathrm{ZrO}_{2}$ films containing $T$ phase had been made.

In this paper, the microstructure, phase, and mechanical properties of the $\mathrm{Y}-\mathrm{ZrO}_{2}$ thin films were investigated. The studies show that the thin films have tiny grains about $88 \dot{A}$, tetragonal phase (60$\left.900^{\circ} \mathrm{C}\right)$, the higher microhardness $\left(2100 \mathrm{kgf} / \mathrm{mm}^{2}\right)$, and the lower wear rate $\left(473 \mathrm{~nm}^{2} /\right.$ cycle $)$. 
2. Experiment

$\mathrm{Y}-\mathrm{ZrO}_{2}$ thin $\mathrm{f}$ ilms were deposited by the reactive $r . f$. magnetron sputtering. The target was a tetragonal $\mathrm{ZrO}_{2}$ polycrystal doped with 2.2 mol\% $\mathrm{Y}_{2} \mathrm{O}_{3}(\mathrm{Y}-\mathrm{TZP})$. The spacing of the substrate-target was $4 \mathrm{~cm}$. The base pressure was below $8 \times 10^{-4} \mathrm{~Pa}$. A mixture of the argon-oxygen gas at the required partial pressure ratio was introduced. The oxygen partial pressure $\left(\%_{2}\right)$ and the substrate temperature ( Ts ) were controlled during deposition. The substrates were the Si wafers or the fused silica. The microstructure and phase of the films were examined by transmission electron microscopyi ( TEM ) and X-ray diffraction ( XRD). A quantitative evaluation of the amounts of monoclinic and tetragonal phases was made by the method (9). The knoop hardness of the films which were deposited on the Si wafe was measured by using a nMT-3 indenter instrument. The wear rate of the films was tested under nonlubricated conditions, using a pin-on-disk tester which applied a $15 \mathrm{~g}$ normal force against the rotating disk through a $10.0 \mathrm{~mm}$ radius hemispherical pin. The Iinear speed of the tested area was, $10 \mathrm{~m} / \mathrm{s}$.

3. Results and Discussion

3.1 Microstructure and phase

The study shows that the films deposited at low Ts and $\% \mathrm{O}_{2}$ have mainly the $T$ phase $(72 \% \mathrm{~T})$ with a small amount of the $M$ phase. As the increments of the $\mathrm{Ts}$ or $\mathrm{O}_{2}$, the amount of $\mathrm{M}$ phase increases, from $28 \%$ to $56 \%, 59 \%$, and $63 \%$. Fig. 1 gives their XRD patterns. Here the $T$ phase identified by not onIy the XRD data but also a ED pattern. The (200) and (220) peaks in the ED pattern were splitted into doublet. This is the character of the $T$ phase rather than the $C$ phase. TEM photographs show that the films possess tiny grains. The grain size of the films was calculated from the line broadening of the $\mathrm{XRD}$ pattern (10) and it was found be $88 \mathrm{~A}$. 


\subsection{Film properties}

The hardness of the films decreased with increasing $\%_{2}$, as shows in the Fig.2. The films deposited at $0.0\left(\% \mathrm{O}_{2}\right)$ and $60 \mathrm{C}(\mathrm{Ts})$ exhibit the maximum hardness of $2100 \mathrm{kgf} / \mathrm{mm}^{2}$. Because the thickness of the films just was 5000-6500A, so the values of the hardness included the effect of the Si(100) substrates, but the effect of the substrates was invariant. Substrate heating leads to the relaxation of the film structure and the reduction of compressive stress in the films and results in the hardness drop.

The wear rate of the films increased with increasing $\%_{2}$, Fig. 3 . The films have the highest resistance against wear failure, or the lowest wear rate $473 \mathrm{~nm}^{2} /$ cycle when the hardness reaches maximum value.

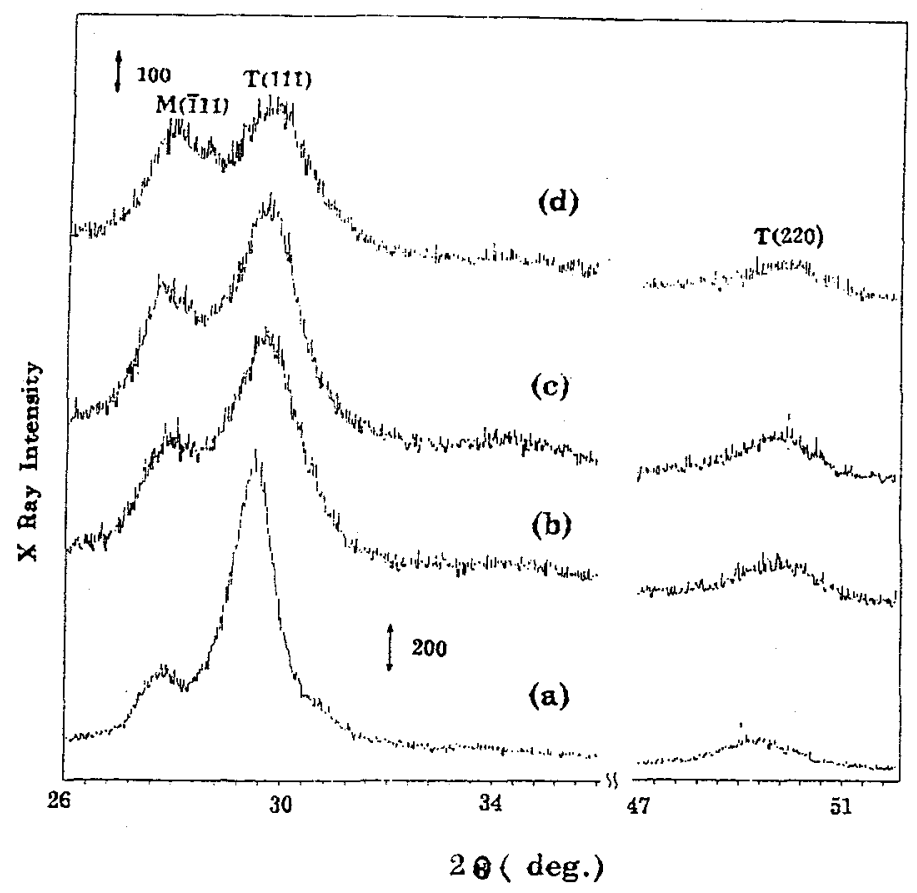

Fig.1. XRD patterns of $\mathrm{Y}_{-2 \mathrm{ZO}_{2}}$ thin films deposited at Ts $=60^{\circ} \mathrm{C}$ with $\% \mathrm{O}_{2}=0.0 \%$ (a), $3.3 \%$ (b), $13.0 \%$ (c), and $\mathrm{Ts}=170^{\circ} \mathrm{C}$ with $\% \mathrm{O}_{2}=13.0 \%$ (d) 


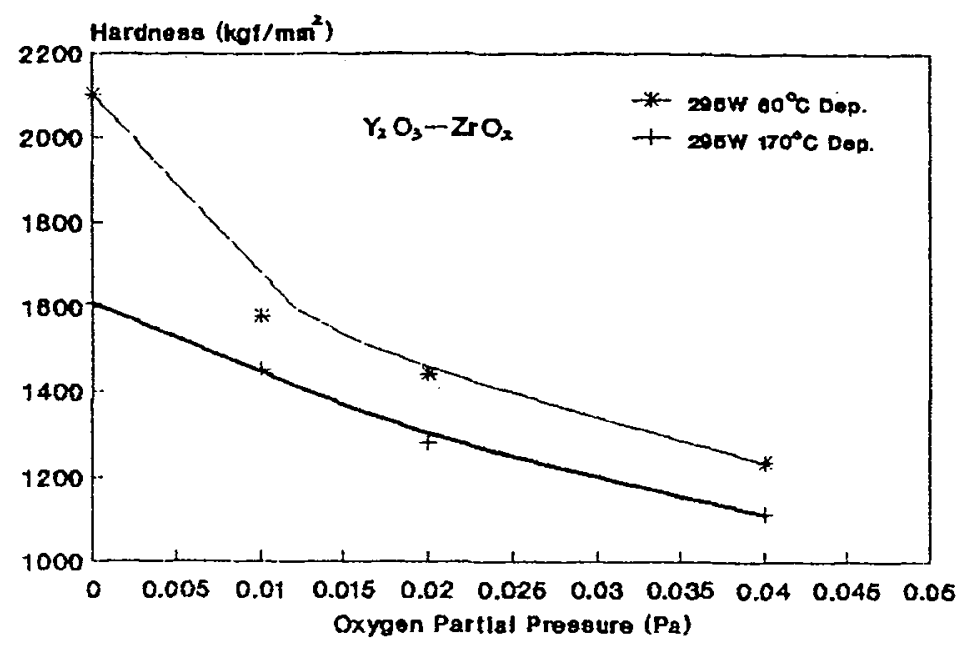

Fig.2. Variation of knoop hardness of $\mathrm{Y}_{-} \mathrm{ZrO}_{2}$ thin films as a function of the $\%_{2}$

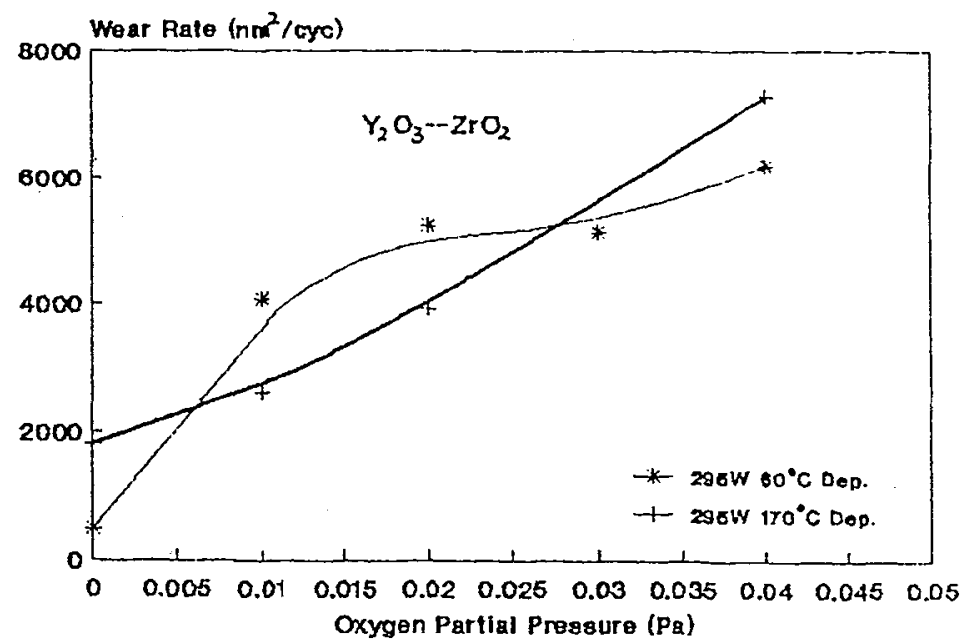

Fig.3. Variation of wear rate of the $\mathrm{Y}-\mathrm{ZrO}_{2}$ thin films as a function of the $\mathrm{\% O}_{2}$ 
4. Conclusions

The $\mathrm{Y}_{-\mathrm{ZrO}_{2}}$ films deposited by $\mathrm{r} . \mathrm{f}$. sputtering from $\mathrm{Y}-\mathrm{TZP}$ target possess mainly tetragonal phase with a small amount of monoclinic phase. However the monoclinic phase increased as increasing $\%_{2}$ and Ts. When the $\% \mathrm{O}_{2}=0.0 \%$ and $\mathrm{Ts}=60^{\circ} \mathrm{C}$ the films have tiny grains about $88 \mathrm{~A}$ the maximum hardness $2100 \mathrm{kgf} / \mathrm{mm}^{2}$, and the lowest wear rate $473 \mathrm{~nm}^{2} /$ cycle.

\section{References}

1. R.Rujkorakarm and J.R.Sites, J. Vac. Sci. Technol. A4, 568 (1986).

2. F.Jones, J. Vac. Sci. Technol. A6, 3088 (1988).

3. J.W.Lee, T.E.Schlesinger, A.K.Stamper et al., J. Appl. Phys. 64,6502 (1988)

4. T.Yamashite, G.L.Chen et al., IEEE. Trans. Magn. 24, 2629 (1988).

5. A.S.Kao, C.Hwang, J. Vac. Sci. Technol. A8, 3289 (1990).

6. M.M.Yang, M.Reith, C.J.Iin, J. Vac. Sci. Technol. A8, 3925 (1990).

7. A.K.Stamper, D.W.Greeve et al., J. Appl. Phys. 70, 2040 (1991).

8. N.Claussen, M.Ruhle, A.Heuer (eds), Science and Technology of $\mathrm{ZrO}_{2}$, Advances in Ceramics II vol. 12, American Ceramic Society Columbus, Ohio, 1984. P.325.

9. R.Fillit, P.Homerin, J.Schafer, H.Bruyas, F.Thevenot, J.Mster. Sci. 22, 3566 (1987).

10. B.D.Cullity, Elements of X-ray Diffraction, Addison-Wesley, 1978, P.284. 